https://doi.org/10.46344/JBINO.2020.v09i5b.08

\title{
TO STUDY THE SADYA PRANHAR MARMA WITH SPECIAL REFERENCE TO HRUDAY MARMA
}

\author{
Dr. Chandrakant S. Shinde \& Dr. Rahul Banarase \\ Lecturer, Rachana Sharir Deptt, Ashvin Rural Ayurved college, Manchihill \\ Associate Professor, Rachana Sharir Deptt. Ashvin Rural Ayurved College, Manchihill
}

Email: dr.chandrakantshinde55@gmail.com

\begin{abstract}
Marma are vital centres or subtle energy fields of the body. Marmas are important aspect in yogic practices with which ayurveda is closely connected. Marmas are related to the 7 chakras (energy centre) and 14 nadis(subtle channel)systems emphasized in yogic thought. Yoga not only has a sophisticated system of physical postures, it also recognizes the power of Prana(life force) which is reflected through the marma points on the surface of the body.In present paper we are discussing regarding the pranahar marma in reference to hudaya marma.
\end{abstract}

Keywords: Marma, Hrudaya Marma,

\section{No: of References: 12}




\section{INTRODUCTION}

Marma are said to be the sites where there is the conglomeration of Mamsa, Sira, Snayu, Asthi and Sandhi and at these places Prana resides specially by nature. Marma are constituted by six vital elements i.e., Soma, Maruta, Tejas, Satva, Raja and Tama and where Jivatma resides. Hence, any injury to Marma proves to be fatal. (Su. Sha.6/ 46) All the classics analogously opine for 107 Marma [3] in the body but on point of narration only three of them Trimarma - Sirah, Hridaya and Vasti are mentioned. Marma of the trunk are more vital than the Marma of extremities, as the extremities are connected to and depend on the trunk. Even among the Marma of trunk Trimarma are more important. TRIMARMA: Marma Traya are included in Pranayatana i.e. site of Prana. As the base is destroyed, the dependent is also destructed. Likewise, the destruction of any of the three Marma may destroy the Prana. One should protect these three Marma from external as well as internal injuries. Trimarma included in Sadyahpranahara Marma. Sirah: All the sense organs and the channels carrying the sensory and vital impulses from the Sirah are like the rays from the sun. This verse truly signifies Sirah as a Trimarma as it correlates it completely to the Brain. Hridaya: It is a structure which resembles a Pundarikena, Kamalamukulakaram (lotus) in inverted position. When body is in active phase it expands and contracts in inactive phase.

Ayurveda, the ancient Indian system of medicine incorporates within itself not only the techniques of treatment described in the Samhita texts but also elaborates structural perspectives in the Sharirsthana of Samhitas. The Sharirsthana of Sushrut Samhita outstands among all Samhitas in describing even minute details of anatomy. It is only here that Acharya Sushruta has described a very vital topic under 'Marmavigyana'. Marmavigyan, is a science that was preserved and associated largely as a support to martial arts and warfare can now be used and applied for normal healing on a wide range of physical and mental diseases as a result of research and application. According to Ayurvedic texts, the Marmas are the points, which when injured, may be life threatening. Marmas are not superficial landmarks on the body surface but these are deep seated important physioanatomical structures. The juncture of mamsa(musce), sira(vessels), snayu (tendon, ligament), asthi(bones), and sandhi(joints) where Dwadash Prana take abode is known as Marma. [5] It is also known as jeevasthana/pranayatana and is source of energy. (marmani naam mansa sira snayu asthi sandhi sannipata, tesu swabhavata ev viseshana pranastisthanti, tasmanmarmasu abhihitan styan bhavanapadyante.). Marma points are specific areas on the body which has relation to various internal organs, doshas, and strotas. [ An important principle of marma therapy is quite simple, where a strong blow can cause injury, a mild touch can cause healing and this is most important principle of marma massage.[4] As in Sushrut Samhita there is description of siravedha agnikarma and kshara karma as treatment procedures having effect on treatment procedures having 
pathogenesis, may be away from that areas.[5] Likewise marma points are specific areas on the body having inter relation with various internal organs and strotasas therefore leading to control (suppression or stimulation) of these system by marma points. There is no direct mention of therapeutic use of Marma Therapy in Ayurvedic texts. But Marma Therapy has recently evolved a lot and based on utilization of 107 points in the body which are considered as access points to body, mind and consciousness.

Pain is the commonest and biggest problem in human beings. Pain can be explained in terms of symptoms underlying another disease or complications of the other disease. The word disease itself symbolizes a painful condition. Pain can be described as any physical suffering or discomfort caused by illness or injury. Ayurveda explains the origin of pain is due to vitiated vata dosha, once vata dosha is treated efficiently the pain subsides automatically. Marma are also an important aspect of the science of yoga, with which ayurveda is closely connected. Yoga reflects the physiological view of Ayurvedic medicine with its doshas, tissue, and channel systems, including the role of marmas. Its aim is to lift awareness to a higher consciousness that transcends pain and suffering, towards this goal, the science of yoga employs many practices and techniques. Asana or yoga posture work on our physical body to release stress, eliminate toxins and balance our physical energies. This is followed by internal methods of Pranayama (breath control) and Pratyahara (control of the senses) to calm and balance our vital energy. Marmas are related to the chakra and nadis(subtle channel) systems, emphasized in yogic practices. Yoga not only has a sophisticated system of physical postures, it also recognizes the power of prana or the life-force which is reflected through the marma points on the surface of the body. An understanding of marmas can add efficacy to any level or type of yogic practice whether using the body, the breath or the mind. This makes it an important tool of energetic/pranic healing.

\section{DISCUSSION}

The anthropometric dimensions of Marma points are an extremely extensive research for every ayurvedic clinician. It is useful in various types of trauma due to different factors of body as well incidents occurring during various surgeries, removal of varied types of foreign bodies from different areas of body, warfare wounds, attacks of wild animals during those days and also the various troubles of Panchkarma therapy. The severity of Marma has been evaluated as above where post trauma commonly gives healing results. But sushruta has already emphases regarding the alteration of the post traumatic result depending upon the severity irrespective of the site The clinical aspect of Marma is elaborated by Sushruta was to avoid damage or injury to the important structure during surgery. Acharya Charaka explains the concept of TriMarma while considering the origin and practical utility of Marma. It provides great importance to the three Marma namely Shir, Hridaya and Basti out of 107 Marma and for that reason 
contained in the ten Pranayatana. The anthropometric knowledge of Marma is of more useful during Surgery, because of the fact that injury to the Marma point, may lead to loss of life immediately or later by problems or result in deformity of a specific area of the body. Surgeon must know the dimension of every Marma and the harms of the Marma point injury so that he can make incision carefully while during any surgical condition. This raises the query that under present advancement of the surgery any kind of Marma and subsequent predominant anatomical structure is manageable? Sushruta has already answered the query by the observation mentioned in the classical books. It also shows the awareness of the future development of the surgery which may possibly indicates the prognostic status of different Marma mentioned in ancient period. Conclusively it may be said that intensity of trauma may alter the prognostic state of Marma. However a skill surgeon may save the patient from disaster. The importance of surgical tissue has been laid down with respect to mode of injury, its dimensions and the kind of weapon used, this also shows that classical view is not conservative on prognostic status of any Marma and prospective development of weaponry was anticipated. Sushruta was also considered in the Traumatology the importance of management given to the patient, which is confirmed by war experiences. Despite the discoveries since the period of Sushruta organized care of the acute injured is comparatively recent innovation. As result of improvement which enhanced the expertise of Vaidya (doctor) the morality rate dropped markedly to $4.5 \%$ in World War II which has already been mentioned in classical note of Sushruta that skilled Vaidya can save the trauma person inflicted at Marma sthana but not before the cost of residual loss. Mortality and morbidity were both shown to improve if patients with the serious wounds were evacuated within ten days after wounding. This shows the first week is considered to be very important from the mortality point of view and such vital areas along with its anthropometric dimensions were isolated by Sushruta under the category of Sadya Pranahar Marma where skilled management and rapid intervention are desired. Majority of these regions belong to fatal group as in case of head, abdomen and chest where all these Marma belong to fatal group. This indicates that head, neck and trunk are comparatively more significant than the extremities, which has been also observed by Acharya Sushruta.

\section{REFERENCES:}

Samhita S, Acharya YT (2008) Susruta Samhita with Nibandha Sangraha of Dalhanacharya. 8th (Edn.), Varanasi: Chaukhambha Orientalia, pp: 369.

2. Chaurasia BD (2004) Human Anatomy, part I.4th (Edn.), New Delhi: BSP ublishers \& Distributors.

3. Samhita S, Atridev V, Banarasidas $M$ (2002) New Delhi, pp: 324.

4. Ashtanga Hrudaya, Bhisagacarya HP (2005) Ashtanga Hrudayam with Sarvangasundara of Arunadatta \& Ayurvedarasayana of Hemadri. Varanasi: Chaukhambha Orientalia. 
5. Acharya VJT (2008) Caraka Samhita revised by Caraka and Drdhabala with Sri Cakrapanidatta Ayurvedadipika Commentary in Sanskrit by, editor. 5th (Edn.), Varanasi: Chaukhambha Sanskrit Sansthan.

6. Samhita S, Sharma A (2004) Sushrutvimarshanitika, volume II, chaukhamba surbharati prakashan pp: 99.

7. Pastore HA, Miaer MP (2001) Anatomical Consideration of Trimarma, (Sharir Rachna). World Journal of Pharmaceutical Research 4(9): 700-704. 8. Das S (2001) A Concise Textbook of Surgery, 3rd (Edn.), Calcutta.

9. Chaurasia BD (2004) Human Anatomy, part I.4th (Edn.), CBS Publishers \& Distributors. New Delhi.

10. Tanwar AK (2015) Importance of Ayurvedic Marma Vigyan", published in ayurveda- for healthy living monthly magazine, Govt of NCT Delhi.

11. Vijaynath A (2010) Comprehensive Study of Marma $s$ in the Hasta (Hand) WSR to the Surface and Regional Anatomy, VSDM College of Ayurveda, Udupi.

12. Moore K, Dalley AF (2006) Clinically Oriented Anatomy, 5th (Edn.), Baltimore: Lippincott Williams \& Wilkins, pp: 1209.

13. Samhita S, Tika V, Sharma A (2004) Volume II, Chaukhamba Surbharati Prakashan, pp: 99.

14. Samhita S, Acharya YT (2008) Susruta Samhita with Nibandha Sangraha of Dalhanacharya. 8th (Edn.), Varanasi:

Chaukhambha Orientalia.
15. Samhita S, Tika V, Sharma A (2004) Volume II, Chaukhamba Surbharati Prakashan, pp: 17. 16. Hrudaya A, Bhisagacarya HP (2005) Ashtanga Hrudayam with Sarvangasundara of Arunadatta \& Ayurvedarasayana of Hemadri. Varanasi: Chaukhambha Orientalia.

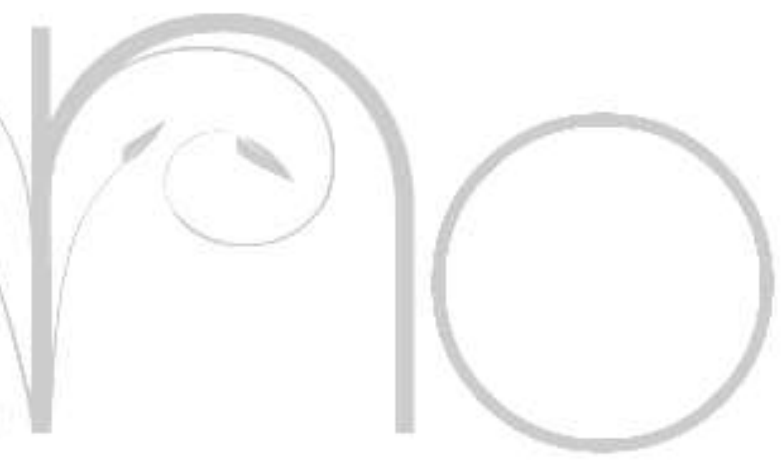

2020 September Special Issue Edition | www.jbino.com | Innovative Association 